\title{
Recent developments of the right to self-determination before the International Court of Justice: The Chagos Advisory Opinion
}

\author{
A Ghimisi ${ }^{1}$ \\ ${ }^{1}$ National University of Political Studies and Public Administration \\ E-mail: ghimisi4567@gmail.com
}

\begin{abstract}
The paper: "'Recent developments of the right to self-determination before the International Court of Justice: The Chagos Advisory Opinion wishes to tackle a very difficult and sensible subject, the right of peoples to self-determination. This case was specifically chosen because of its peculiarities regarding the subject and their developments going as early as the first principles of the International Court of Justice and reaching into present time. Through the analysis, key findings will be presented in order to grasp the fully extension of the principle and how it was developed over time, ultimately evolving into a basic human right.
\end{abstract}

Keywords: self-determination, human right, Chagos

\section{Introduction}

The principle of self-determination is a complex topic with has suffered many modifications through history, ultimately evolving into a "right". It rose in a delicate time and came as an answer to colonialism, but also presented the means to means to end it. Through time, this principle needed to be embodied and acknowledged by all countries as being one of the fundamental principles of international law and human rights. Even though this right has been presented and implemented into the United Nations Charter, going from the creation of the U.N and coming into today's time, there are still some cases in which this principle, right had been stopped in achieving its purpose

I find it both interesting and worrying the fact that a principle that was crystalized over 50 years ago is still perceived in different ways by multiple countries. I consider that in the light of todays time, there cannot be second guessing when we talk about a right that speaks of fundamental human rights. The right of people to self-determination needs to be an erga omnes feature and it must be respected in accordance with this fundamental principle of international law. Not only does this principle need to be protected, it also needs to be developed and evolving with today's international legislation. Even though this principle evolved into today's time to become a right, it seems that there still are some cases in which this right is not respected and the ones who suffer the most from it are the people of the respective territory. Because of these factors, I was driven into my research, more specifically into analysing the latest case presented in front of the International Court of Justice, namely The Chagos Advisory Opinion. 
My research question: "what are the recent developments regarding the rights of selfdetermination?" is presented in strong connection with the case mentioned above because of its peculiarities in the matter discussed. Of particular importance is the fact that this case searches for an answer on a question that conceived its answer going back to early beginnings of the U.N. This case is the latest to be brought in front of the I.C.J, and concerns not only the right to self-determination but also the legal consequences of such a continuing unlawful act in regards to the people and territory of a Member State. For me, this case is of relevance because it presents a right that was embodied in the United Nations Charter, a right of which an administering power didn't consider to be important when achieving its purposes. In addition, I believe that an important connection is presented regarding the right of people to self-determination in connection with the process of decolonization and territorial integrity.

\section{Events leading to the adoption of the request for the advisory opinion}

"The Chagos Archipelago consists of a number of islands and atolls. The largest island is Diego Garcia, which is located in the south-east of the archipelago. With an area of about $27 \mathrm{sq} \mathrm{km}$, the island Diego Garcia account for more than half of the archipelago's total land area.

Between 1814 and 1965, the Chagos Archipelago was administered by the United Kingdom as a dependency of the colony of Mauritius. From 1926, Governor Lowry-Cole listed the islands of the Chagos Archipelago as dependencies of Mauritius. The islands were also presented in several ordinances. The Mauritius Constitution Order of 26 February 1964, promulgated by the government of the United Kingdom, defined the colony of Mauritius in section 90(1) as "the island of Mauritius and the Dependencies of Mauritius

On 8 November 1965, by the British Indian Ocean Territory Order1965, the United Kingdom created a new colony known as the British Indian Ocean Territory ("BIOT") consisting of the Chagos Archipelago, detached from Mauritius, and the Aldabra, Farquhar and Desroches islands, detached from Seychelles.

On 16 December 1965, the General Assembly adopted resolution 2066(XX) on the "Question of Mauritius", in which it expressed deep concern about the detachment of certain islands from the territory of Mauritius for the purpose of creating a military base. It invited the "administering Power to take no action which would dismember the Territory of Mauritius and violate its territorial integrity".

On 20 December 1966, the General Assembly adopted resolution 2232(XXI) on the number of territories including Mauritius. The resolution reaffirmed that: "any attempt aimed at the partial or total disruption of the national unity and the territorial integrity of colonial Territories and the establishment of military bases and installations in these Territories is incompatible with the purposes and principles of the Charter of the United Nations and of General Assembly resolution 1514 (XV)".

Mauritius was Sir Seewoosagur Ramgoolam. Section 111, paragraph 1, of the 1968 Constitution of Mauritius, promulgated by the United Kingdom Government before independence on 4 March 1968, defined Mauritius as "the territories which immediately before $12^{\text {th }}$ March 1968 constituted the colony of Mauritius". This definition did not include the Chagos Archipelago in the territory of Mauritius.

Between the years 1967 and 1973, the entire population of the Chagos Archipelago was either prevented from returning or forcibly removed and prevented from returning by the United Kingdom. The main moment of the forcible removable of the population of Diego Garcia was in July 1971"

On 11 April 1979, in a discussion on the detachment of the Chagos Archipelago, Prime Minister Ramgoolam told the Mauritian Parliament "we had no choice".

In July 1980, the Organisation of African Unity, OAU, adopted resolution 99 (XVII) (1980) in which it "demands" that Diego Garcia be "unconditionally returned to Mauritius".

In the same year, the Mauritian Prime Minister, at the thirty-fifth session of the United Nations General Assembly, presented that the BIOT should be disbanded and the territory restored to Mauritius as part of its natural heritage. 
In July 2000, the OAU adopted Decision AHG/Dec.159 (XXXVI) (2000) expressing its concern that the Chagos Archipelago was "excised by the colonial power from Mauritius prior to its independence in violation of UN Resolution 1514".

On March 2015, the Arbitral Tribunal constituted under Annex VII of UNCLOS rendered an award in the Arbitration regarding the Chagos Marine Protected Area between Mauritius and the United Kingdom. In its award, the tribunal found that it lacked jurisdiction on Mauritius first, second and third submissions, but had jurisdiction to consider Mauritius fourth submission. With respect to the first submission, the Tribunal observed that "the parties dispute regarding sovereignty over the Chagos Archipelago does not concern interpretation or application" of UNCLOS

On 30 December 2016, the 50-year period covered in the 1966 Agreement came to an end, however, it was extended for a further period of twenty years, in accordance with its terms.

On 30 January 2017, the Assembly of the African Union adopted resolution AU/Res.1 (XXVIII) on the Chagos Archipelago, which resolved, among other things, to support Mauritius with a view to ensuring "the completion of the decolonization of the Republic of Mauritius". In the same year, on the $23^{\text {rd }}$ of June, the General Assembly adopted resolution 71/292 requesting an advisory opinion from the Court.

Having recalled the events leading to the adoption of the request, I will continue by presenting the consideration regarding the jurisdiction and discretion of the Court.

\section{The jurisdiction and discretion of the International Court of Justice}

In accordance with the jurisprudence and applicable law of the Court, three requirements need to be met in order for the Court to give its advisory opinion. The first requirement is that only competent organ or organization can request the Court to exercise its advisory jurisdiction, the next requirement is that questions must be of legal nature and the third one refers to whether is it proper for the Court to exercise its jurisdiction.

Going further into the subject, the jurisdiction of the Court is one matter to tackle. When presenting their arguments in the written statements, when it comes to jurisdiction and the authorized organ or organization that presented the request, states mostly focus their attention on Article 65(1) of the Statute of the Court and Article 96(1) of the Charter of the United Nations.

In the case of the Construction of a Wall in 09 July 2004, in its advisory opinion the Court found that the view that it has no jurisdiction because of the political character of the question posed was not acceptable. The Court considered that the political aspects that derive from the question does not deprive it of its character as a legal question and therefore, it cannot deprive the Court of a competence that is expressly conferred by its Statute. The Court concluded that it has jurisdiction to give the advisory opinion requested by Resolution of the General Assembly.

The next matter at hand is the discretionary power of the Court. Regarding the ability of the Court to exercise its discretion in giving the advisory opinion. Even if the conditions for jurisdiction are met, the Court has interpreted Article 65(1) of its Statute as giving it discretion to render or refuse to render the opinion requested [1] However, the present Court has never refused to give an advisory opinion through the exercise of its discretion. As the Court has repeatedly stated: "the reply of the Court, itself an 'organ of the United Nations', represents its participation in the activities of the Organization, and, in principle, should not be refused [2]." The Court has further sustained that only "compelling reasons" should serve as a basis for the Court to exercise its discretion to decline to issue an opinion [3]. Further information's are discussed largely in the paper and are developed more in order to understand where the limits of this status of the Court are.

Both the United Kingdom and Mauritius, as well as other countries that wanted to participate to help the Court in making its final decision could do so by presenting their written or oral arguments. As a main conclusion regarding this aspect, the Court concluded that in the present proceedings they could not decline to answer the questions posed to it by the General assembly in in resolution 71/292 on the ground that its opinion would not assist the General Assembly in the performance of its functions. Because of the factors and circumstances mentioned, the Court does not consider that giving 
the opinion requested would have the effect of circumventing the principle of consent by a State to the judicial settlement of its dispute with another State. The Court therefore cannot, in the exercise of its discretion, decline to give the opinion on that ground. In addition, in the light of the foregoing, the Court concludes that there are no compelling reasons for it to decline to give the opinion requested by the General Assembly.

4.The Advisory Opinion

After presenting the events that lead to the adoption of the advisory opinion and the strong cases made both against and in favour of the Court jurisdiction and discretion, the Advisory Opinion will be analysed through multiple stages. A clear analysis of the relevant time period and the rules that can be applied in regards to international law is needed, alongside the functions of the General Assembly with respect to the matter of decolonization and relevant cases that can offer a good insight in matters already acknowledged.

The main questions that were addressed to the Court in order to be settled[4]:

A) "Was the process of decolonization of Mauritius lawfully completed when Mauritius was granted independence in 1968, following separation of the Chagos Archipelago from Mauritius and having regard to international law, including obligations reflected in General Assembly resolutions 1514 (XV) of 14 December 1960, 2066 (XX) of 16 December 1965, 2232 (XXI) of 20 December 1966 and 2357 (XXII) of 19 December 1967.“

B) "What are the consequences under international law, including obligations reflected in the above-mentioned resolutions, arising from the continued administration by the United Kingdom of Great Britain and Northem Ireland of the Chagos Archipelago, including with respect to the inability of Mauritius to implement a programme for the resettlement on the Chagos Archipelago of its nationals, in particular those of Chagossian origin? ".

In regards to the relevant time period for the purpose of identifying the applicable rules of international law, it has been judged upon that , the right of self-determination had already crystalized before the Chagos Archipelago was excised in 1965. The corollaries of that right had crystalized as well. As expressed in the Colonial Declaration, those corollaries included the right to "territorial integrity" and the right of peoples to "freely determine their political status", norms that the Court has suggested help to "confirm and emphasize that the application of the right of self-determination requires a free and genuine expression of the will of the peoples concerned"[5]

After the problem of the relevant time period has been settled, the arguments of both parts are presented. The view of the two main actors and their response to the questions presented on this topic are again the main focus. To sum up, the United Kingdom underlines some of the most important aspects that were presented in their arguments. The fact that the elected representatives of Mauritius agreed freely to the detachment of the Chagos Archipelago in the 1965 Agreement in connection with the reaffirmation of the Agreement in the Chagos Arbitration are elements that are highlighted by the UK. Also, they consider that there was no settled practice or opinion juris to support Mauritius argument that paragraph 6 reflected customary international law. Finally, an international law right to self-determination did not come into existence or bind the United Kingdom until after the end of the 1960s and therefore had no impact on the lawful completion of Mauritius decolonization in 1968.

As for Maurtius and their arguments, one important argument that stands out in Mauritius statement is the fact that Central to the right of self-determination is the requirement that the future of a Non-Self-Governing Territory is to be determined by the free expression of the will of the entire people of the territory. Such an expression of will was lacking in respect to the excision of the Chagos Archipelago from Mauritius. The reluctant and forced acquiescence, at the Constitutional Conference in 1965, of the Mauritian representatives - who were compelled to accept the excision only when it was presented to them as a foregone conclusion and as the inescapable price of independence - can be no substitute for a free expression of the will of the people.

For the reason presented above, and many others well described by other countries, Mauritius respectfully submits that it is clearly only one answer regarding the first question: the process of 
decolonisation of Mauritius was not lawful completed when Mauritius was granted its independence in 1968 and it remains incomplete today.

After the first question presented to the Court was analysed, the next part of the trial focused on the countries answers with respect to the second question. As was in the case for the question above, the arguments are focussed on Mauritius and the United Kingdom. In very short terms, the response of the United Kingdom in regards to the second question was not developed because they consider the response to be in close connection to the second question, which they already consider not to be fit to present in front of the Court. Furthermore, the United Kingdom recognized the legal consequences that were drawn out in the 2015 Chagos Arbitration Award.

As for Maurtius and their arguments with respect to the second question, in the final remarks of their argument, Mauritius concludes that the failure to complete the decolonisation carries the legal consequence that the continuing wrongful act must come to an end and Mauritius decolonisation must be completed immediately. This can only be achieved when the administering power has fully withdrawn its administration from the Archipelago and Mauritius is able to exercise its full rights of sovereignty. In addition, the administering power must recognise Mauritius sovereignty over the Chagos Archielago. The period of time in which this must come to competition, taking into account the principle of the colonial arrangements which must be brought to a speedy end, should be less than a year given the other, more complex examples offered.

After all arguments are exposed, the decision of the Court is presented in strong connection with the present findings. In the final remarks regarding its opinion regarding the first question, the Court concludes that, as a result of the unlawful detachment of the Chagos Archipelago and its incorporation into a new colony, known as the BIOT, the process of decolonization of Mauritius was not lawfully complete when it acceded to independence in 1968.

Having found that the decolonisation of Mauritius was not conducted in a manner that was consistent with the right of self-determination, the Court concludes that it follows that the United Kingdom's continued administration of the Chagos Archipelago constitutes a wrongful act entailing the international responsibility of that State. In accordance with the situation, the United Kingdom is under an obligation to bring an end to its administration of the Chagos Archipelago as rapidly as possible, thereby enabling the complete decolonisation of Mauritius and its territory in a manner that is consistent with the right of peoples to self-determination.

In regards to the aspect of the resettlement on the Chagoes Archipelago of Mauritian nationals, including those of Chagossain origin, this issue is considered to be relating to the protection of the human rights of those concerned, which needs to be addressed by the General Assembly during the completion of the decolonization of Mauritius.

To sum up and offer a response to the second question relating the consequences under international law that arise from the continued administration by the United Kingdom of the Chagos Archipelago, the Court concludes that the U.K has an obligation to bring to an end its administration of the Chagos Archipelago as rapidly as possible, and that all Member states must co-operate with the United Nations to complete the decolonization of Mauritius.

\section{Conclusion}

In conclusion, I want to pin point out some important aspects that are better developed in the paper, which will share some insight on the topic.

From my point of view, this case was of particular relevance to the topic because it involves a right that was seen by many to have been crystallized a very long time ago. Even though there are fewer and fewer cases in regards to this topic, it seems that there are still some examples that have their roots in the beginning of the United Nations. This case shows how, even if the right of self-determination has been acknowledged in multiple occasions in the past decades, it still needs to be not only developed, but protected in order for such an event not to happen again. Moreover, this case shows how an administering power, even if presented with several occasions and requirements to cease its 
governance over the territory and the people living on it, refuses to do so and also seeks to not respect an international legislation procured by the international institution, from which it is a part of.

Another interesting factor is that even though there was an understanding of a long going bilateral dispute, which was previously searched in other cases, the matter still is analysed as an issue of selfdetermination and also human rights. The applicable law and time frame are two other important elements that rose from this case as particular because the question was posed to General Assembly resolutions that were prior to independence. Furthermore, probably the most important element regarding this research was the fact that the consent was given under duress.

Through the findings, it is clear that Mauritius had little to no chance in achieving its full independence, with the Chagos Archipelago, and thus accepted the terms presented to it. The problem of the unlawful removal of the people of the Chagos Archipelago and in particular those of Chagossian origin is another peculiar aspect in this case. Moreover, this case is of upmost importance it was the first time when such a continued administration of a territory in seized in the present day. This cases, offers a new pillar in the construction of self-determination as a true erga omnes right. The echoes of this case will still be present in the coming years, as it shows the fact that it doesn't matter which state you are, the right of self-determination of peoples must be respected and conducted accordingly.

In conclusion, after addressing all this issues and having in mind all the findings, the Court offered their advisory opinion and in doing so concluded that the process of decolonization was not lawfully completed and that the United Kingdom must bring its continued administration to an end as rapidly as possible. So what is the relevance of the case in regards to self-determination, decolonization and territorial integrity? For starters the fact that it depicts a continuous unlawful administration of a territory for more than over 50 years is an intriguing factor when almost every case regarding selfdetermination were either resolved by the time of the implementation of the United Nation resolutions or in the years that follow.

\section{References}

[1] Legal Consequences of the Construction of a Wall in the Occupied Palestinian Territory, Advisory Opinion, J. C.J. Reports 2004

[2] Interpretation of Peace Treaties with Bulgaria, Hungary and Rumania, First Phase, Advisory Opinion, /. C. J. Reports 1950

[3] Judgments of the Administrative Tribunal of the ILO upon Complains Made against UNESCO, Advisory Opinion, I.C.J. Reports 1956

[4] Ghimisi A, Recent developments of the right to self-determination before the International

Court of Justice: The Chagos Advisory Opinion, Dissertation, SNSPA, 2019

[5] Western Sahara, Advisory Opinion, I.C.J. Reports 1975 